\title{
Assessment of Diversity in Claviceps africana and Other Claviceps Species by RAM and AFLP Analyses
}

\author{
Paul W. Tooley, Nichole R. O’Neill, Erin D. Goley, and Marie M. Carras
}

First, third, and fourth authors: U.S. Department of Agriculture-ARS, Foreign Disease-Weed Science Research Unit, 1301 Ditto Ave., Ft. Detrick, MD 21702; and second author: Soybean and Alfalfa Research Laboratory, U.S. Department of Agriculture-ARS, Beltsville, MD 20705.

Accepted for publication 13 June 2000.

\begin{abstract}
Tooley, P. W., O'Neill, N. R., Goley, E. D., and Carras, M. M. 2000. Assessment of diversity in Claviceps africana and other Claviceps species by RAM and AFLP analyses. Phytopathology 90:1126-1130.

Genetic diversity among isolates of Claviceps africana, the sorghum ergot pathogen, and isolates of other Claviceps spp. causing ergot on sorghum or other hosts, was analyzed by random amplified microsatellite (RAM) and amplified fragment length polymorphism (AFLP) analyses. Of the RAM primer sets tested, one revealed polymorphism in $C$. africana isolates, with Australian and Indian isolates possessing a unique fragment. AFLP analysis, in addition to clearly distinguishing Claviceps spp., revealed polymorphisms in C. africana. A group of isolates from the United States, Puerto Rico, and South Africa exhibited 95 to $100 \%$

similarity with one another. Several isolates from Isabela, Puerto Rico were $100 \%$ similar to an isolate from Texas, and another isolate from Puerto Rico was identical with one from Nebraska. Australian and Indian isolates showed greater than $90 \%$ similarity with isolates from the United States., Puerto Rico, and South Africa. A number of polymorphisms existed in the United States group, indicating that the recently introduced population contains multiple genotypes. Isolates of $C$. sorghicola, a newly described sorghum pathogen from Japan, were very distinct from other species via RAM and AFLP analyses, as were isolates from outgroups $C$. purpurea and $C$. fusiformis. Both RAM and AFLP analysis will be useful in determining future patterns of intercontinental migration of the sorghum ergot pathogen, with the AFLP method showing greater ability to characterize levels of intraspecific variation.
\end{abstract}

Ergot of sorghum (Sorghum bicolor (L.) Moench) caused by Claviceps africana Frederickson, Mantle, and de Milliano (9) was first discovered in the Western Hemisphere in Brazil in 1995 (22), after initially being restricted to Asia and Africa $(1,2,21)$. In the United States, sorghum ergot was found in the lower Rio Grande Valley of Texas in March 1997 (13) and was reported to occur in Mississippi in October 1997 as well (27). In that year, the disease spread rapidly through Texas and northward as far as Nebraska. The disease is currently a threat to sorghum production in several states including Texas, Kansas, Oklahoma, and Nebraska and has caused heavy losses in some areas.

The pathogen present in the United States was diagnosed as $C$. africana based on morphological characters and ergot alkaloid analysis (13). These criteria differentiate the sorghum ergot pathogen described from India as C. sorghi Kulkarni, Seshadri, and Hegde $(15,18)$, and the African pathogen described as $C$. africana (9). C. sorghicola Tsukiboshi, Shimanuki, and Uematsu (24) is a third distinct species causing sorghum ergot recently described from Japan. C. sorghicola differs from C. sorghi and C. africana in the color and texture of sclerotia, color and morphology of stromata, and size of ascospores and conidia.

Concern for the production of hybrid seed as well as sorghum grain production has led to extensive efforts to better understand the biology of $C$. africana and determine ways to limit its destructive potential. The ergot pathogen infects sorghum at flowering and can substantially reduce seed set in commercial hybrid

Corresponding author: P. W. Tooley; E-mail address: tooley@ncifcrf.gov

Publication no. P-2000-0728-02R

This article is in the public domain and not copyrightable. It may be freely reprinted with customary crediting of the source. The American Phytopathological Society, 2000. seed-production fields. In grain production fields, ergot can attack tillers late in the season and present serious problems at harvest. Sticky honeydew (an exudate containing high concentrations of fungal conidia) is present on harvested seed and can foul equipment and interfere with harvest operations and further distribution of harvested seed.

Little is known of the genetic relationship among Claviceps spp. and particularly $C$. africana isolates causing sorghum ergot. Mycological studies have been performed with $C$. africana and C. sorghi from Africa and India $(1,9,15,17)$, but molecular studies have been few. Recently, Pažoutová et al. (21) studied intraspecific variation in sorghum ergot isolates by random amplified polymorphic DNA (RAPD) analysis.

In 1997, we began collecting $C$. africana isolates from outbreaks in the United States and in other countries (Table 1). Using this collection, we analyzed the sequence of the internal transcribed spacer (ITS) regions and intron 3 of the $\beta$-tubulin gene (23) and determined that U.S. isolates could not be differentiated from $C$. africana isolates from other regions. C. africana isolates as a group were distinguished clearly from four other Claviceps spp., and polymerase chain reaction (PCR) primers were used for identification of the five species. Although these tools allowed interspecific comparisons of Claviceps spp., knowledge of intraspecific diversity in $C$. africana is needed to determine the relationships among U.S. and other isolates of this rapidly emerging pathogen. This information would help determine possible origins of U.S. isolates and to assess the level of genetic variation present in the U.S. C. africana population.

A wide variety of molecular methods exist to assess levels of intraspecific variation in plant pathogenic fungi including restriction fragment length polymorphisms (RFLPs), RAPDs, mitochondrial DNA polymorphisms, microsatellite analysis, amplified fragment length polymorphism (AFLP) analysis, and others $(5,6,19)$. Random amplified microsatellite (RAM) analysis is 
PCR-based with primers containing microsatellite sequences and degenerate anchors at the $5^{\prime}$ ends. This method was useful in describing variation in several groups of fungi (10), including Peridermium pini, the causal agent of the resin top disease of Scots pine (Pinus sylvestris L.) (11).

The AFLP technique $(16,26)$ has been used for genetic characterization of a variety of organisms including bacteria, plants, and nematodes $(3,8,12)$. Recent applications include genetic characterization of plant pathogenic fungi $(7,20,25)$. Within the fungal genera Colletotrichum, Pleospora, and Dendryphion, the AFLP method allowed assessment of pathogen diversity and species determination $(7,20)$.

In this study, we have applied RAM and AFLP techniques to $C$. africana isolates collected from diverse sources to determine relationships among isolates and to assess levels of genetic variation in this new pathogen.

\section{MATERIALS AND METHODS}

Isolates of Claviceps spp. were obtained from various sources or isolated directly from diseased sorghum submitted to our laboratory (Table 1). Cultures were established by diluting honeydew $(\approx 100$-fold $)$ in sterile-distilled water and streaking them on plates of $2 \%$ water agar containing $100 \mu \mathrm{g} / \mathrm{ml}$ of ampicillin and $100 \mu \mathrm{g} / \mathrm{ml}$ of streptomycin sulfate. Plates were incubated at $22^{\circ} \mathrm{C}$ in the dark and individually germinated conidia were transferred to plates of potato dextrose agar where they grew colonies. When samples had low conidial viability, a conidial suspension made in steriledistilled water was used to inoculate flowering heads of susceptible sorghum plants (male sterile lines aTX 623 and aTX 2752, obtained from G. Odvody and D. Frederiksen, Texas A\&M University, Corpus Christi) grown in the USDA-ARS containment greenhouse complex at Ft. Detrick, MD. Fresh honeydew produced on inoculated heads was used to establish singleconidial cultures as described previously. C. africana isolates were sent in pure culture from Australia by M. Ryley (Queensland Department of Primary Industries). Pure cultures of isolates of $C$. purpurea, C. fusiformis, and Pleospora papaveracea (de not.) Sacc. (7) used for outgroup comparisons were obtained from the American Type Culture Collection and collected by the authors.

RAM analysis. The primers used were as described in Hantula et al. (10) and designated by target repeat sequences ACA, CCA, CGA, and GT. PCR was performed in a thermal cycler (Model 9600; Perkin-Elmer, Foster City, CA) with temperature profiles as described in Hantula et al. (10). Annealing temperature was dependent on the specific primer used: $64^{\circ} \mathrm{C}$ for $\mathrm{CCA}, 61^{\circ} \mathrm{C}$ for $\mathrm{CGA}, 58^{\circ} \mathrm{C}$ for $\mathrm{GT}$, and $49^{\circ} \mathrm{C}$ for $\mathrm{ACA}$. PCR products were separated in $1.4 \%$ agarose gels in $0.5 \times$ Tris-borate-EDTA buffer and stained with ethidium bromide.

AFLP analysis. AFLPs were generated with the AFLP Analysis System II (Life Technologies Inc., Gaithersburg, MD) with a modified protocol (16). The primary template was prepared by digesting $250 \mathrm{ng}$ of fungal genomic DNA with EcoRI and MseI to completion and heating to $70^{\circ} \mathrm{C}$ for $15 \mathrm{~min}$ to inactivate the enzymes. The DNA fragments were ligated to the EcoRI and MseI adapters provided in the kit for $2 \mathrm{~h}$ at $200^{\circ} \mathrm{C}$. The ligation mixture was diluted 10-fold with sterile-distilled water, and the fragments were preamplified by 20 PCR cycles with primers in preamp primer mix II (Life Technologies) (26). The preselective amplification was performed in a Perkin-Elmer 2400 thermal cycler with a temperature profile of $94^{\circ} \mathrm{C}$ for $30 \mathrm{~s}, 56^{\circ} \mathrm{C}$ for $60 \mathrm{~s}$, and $72^{\circ} \mathrm{C}$ for $60 \mathrm{~s}$.

Selective primers were obtained from Life Technologies. Preliminary experiments using $M s e \mathrm{I}+\mathrm{C}$ combined with $E c o \mathrm{RI}+\mathrm{AG}$ or EcoRI + AT resulted in the generation of many amplified DNAs, and EcoRI + AG was selected for further use. Five-microliter subsamples of the preamplified fragments were diluted 50-fold and used with unlabeled Mse I $+\mathrm{C}$ primers, and primer EcoRI + AG ${ }^{32} \mathrm{P}$-labeled by the AFLP Analysis System I protocol (Life
Technologies). The PCR amplification temperature profile was one cycle at $94^{\circ} \mathrm{C}$ for $30 \mathrm{~s}, 56^{\circ} \mathrm{C}$ for $30 \mathrm{~s}$, and $72^{\circ} \mathrm{C}$ for $60 \mathrm{~s}$. The annealing temperature was lowered for each cycle by $0.7^{\circ} \mathrm{C}$ for 12 additional cycles; the remainder of the amplification was 23 cycles at $94^{\circ} \mathrm{C}$ for $30 \mathrm{~s}, 56^{\circ} \mathrm{C}$ for $30 \mathrm{~s}$, and $72^{\circ} \mathrm{C}$ for $60 \mathrm{~s}$. The PCR products in $2.5-\mu l$ subsamples were separated by electrophoresis with a denaturing $(6 \%$, wt/vol) polyacrylamide DNA sequencing gel containing $7.5 \mathrm{M}$ urea. Autoradiographs were obtained by exposing BioMax MR-2 film (Eastman Kodak Co., Rochester, NY) to the dried gel overnight at room temperature.

Autoradiographs were scanned on a computer to score each lane for the presence or absence of bands between molecular sizes of 75 and 295 bp using Proscore (Version 2.36; DNA Proscan Inc., Nashville, TN). Only polymorphisms that could be scored unequivocally for presence or absence of bands were included in the analyses; faint bands were never scored as absent. Binary matrices consisting of 0's (denoting absence of a given band) and 1's (denoting presence of a given band) were analyzed to obtain simple matching coefficients among the isolates using NTSYS-pc,

TABLE 1. Claviceps spp. and Pleospora sp. used in this study

\begin{tabular}{|c|c|c|c|}
\hline $\begin{array}{l}\text { Species and } \\
\text { isolate }^{\mathrm{a}}\end{array}$ & Source & Host & Date $^{b}$ \\
\hline \multicolumn{4}{|l|}{ C. purpurea } \\
\hline Clp-1 (34699) & Montana & Hordeum vulgare & NF \\
\hline Clp-2 (34501) & East Germany & Secale cereale & NF \\
\hline \multicolumn{4}{|l|}{ C. fusiformis } \\
\hline Clf-1 (26019) & Africa & $\begin{array}{l}\text { Pennisetum } \\
\text { typhoideum }\end{array}$ & NF \\
\hline \multicolumn{4}{|l|}{ C. africana } \\
\hline Cls-1 & Patancheru, India & Sorghum bicolor & 1997 \\
\hline Cls-2 & Akola, India & Sorghum bicolor & 1997 \\
\hline Cls-3 & Dharwar, India & Sorghum bicolor & 1997 \\
\hline Cls-4 & Patancheru, India & Sorghum bicolor & 1997 \\
\hline Cla-1 & Queensland, Australia & Sorghum bicolor & 1996 \\
\hline Cla-2 & Queensland, Australia & Sorghum bicolor & 1996 \\
\hline Cla-3 & Queensland, Australia & Sorghum bicolor & 1997 \\
\hline Cla-4 & College Station, Texas & Sorghum bicolor & 1997 \\
\hline Cla-5 & College Station, Texas & Sorghum bicolor & 1997 \\
\hline Cla-7 & Isabela, Puerto Rico & Sorghum bicolor & 1997 \\
\hline Cla-8 & Isabela, Puerto Rico & Sorghum bicolor & 1997 \\
\hline Cla-9 & Weslaco, Texas & Sorghum bicolor & 1998 \\
\hline Cla-10 & Weslaco, Texas & Sorghum bicolor & 1998 \\
\hline Cla-12 & Isabela, Puerto Rico & Sorghum bicolor & 1998 \\
\hline Cla-14 & Isabela, Puerto Rico & Sorghum bicolor & 1998 \\
\hline Cla-17 & Isabela, Puerto Rico & Sorghum bicolor & 1998 \\
\hline Cla-25 & Isabela, Puerto Rico & Sorghum bicolor & 1998 \\
\hline Cla-34 & $\begin{array}{l}\text { Guayanilla, } \\
\text { Puerto Rico }\end{array}$ & Sorghum bicolor & 1998 \\
\hline Cla-42 & Virginia, Nebraska & Sorghum bicolor & 1997 \\
\hline Cla-49 & Hale Center, Texas & Sorghum bicolor & 1998 \\
\hline Cla-56 & $\begin{array}{l}\text { Potchefstroom, } \\
\text { South Africa }\end{array}$ & Sorghum bicolor & 1998 \\
\hline Cla-58 & $\begin{array}{l}\text { Potchefstroom, } \\
\text { South Africa }\end{array}$ & Sorghum bicolor & 1998 \\
\hline \multicolumn{4}{|l|}{ C. sorghicola } \\
\hline Cjap-2 & $\begin{array}{l}\text { Nishinasuno, Tochigi, } \\
\text { Japan }\end{array}$ & Sorghum bicolor & 1996 \\
\hline Cjap-4 & $\begin{array}{l}\text { Nishinasuno, Tochigi, } \\
\text { Japan }\end{array}$ & Sorghum bicolor & 1997 \\
\hline Cjap-6 & $\begin{array}{l}\text { Nishinasuno, Tochigi, } \\
\text { Japan }\end{array}$ & Sorghum bicolor & 1996 \\
\hline Cjap-7 & $\begin{array}{l}\text { Nishinasuno, Tochigi, } \\
\text { Japan }\end{array}$ & Sorghum bicolor & 1996 \\
\hline \multicolumn{4}{|l|}{ P. papaveracea } \\
\hline $251083-1$ & Afghanistan & $\begin{array}{l}\text { Papaver } \\
\quad \text { somniferum }\end{array}$ & $\mathrm{NF}$ \\
\hline
\end{tabular}

a Isolates Cls-1 to Cls-4 provided by R. Bandyopadhyay (ICRISAT, Patancheru, India) and isolates Cla-2 and Cla-3 provided by M. Ryley (Queensland Dept. of Primary Industries, Australia). Other C. africana isolates were obtained from ergot-infected sorghum provided by R. Frederiksen, G. Odvody, J. Dahlberg, R. Bandyopadhyay, S. Jensen, N. McClaren, and T. Isakeit. Isolates Cjap-2, Cjap4, Cjap-6, and Cjap-7 were provided by T. Tsukiboshi (National Institute of Agro-Environmental Sciences, Tsukupa, Ibaraki, Japan).

${ }^{\mathrm{b}}$ Not found. 


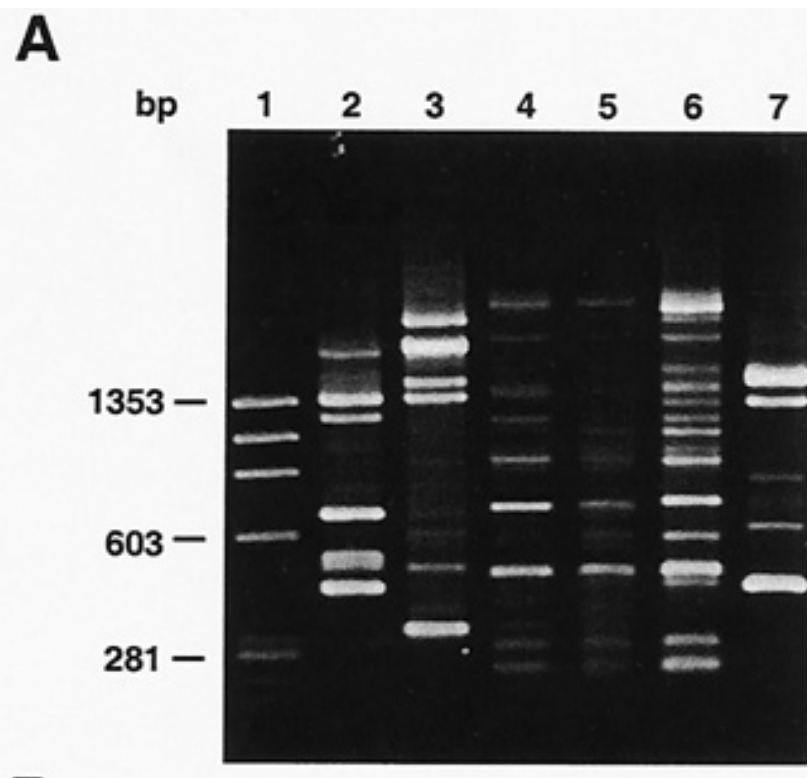

B

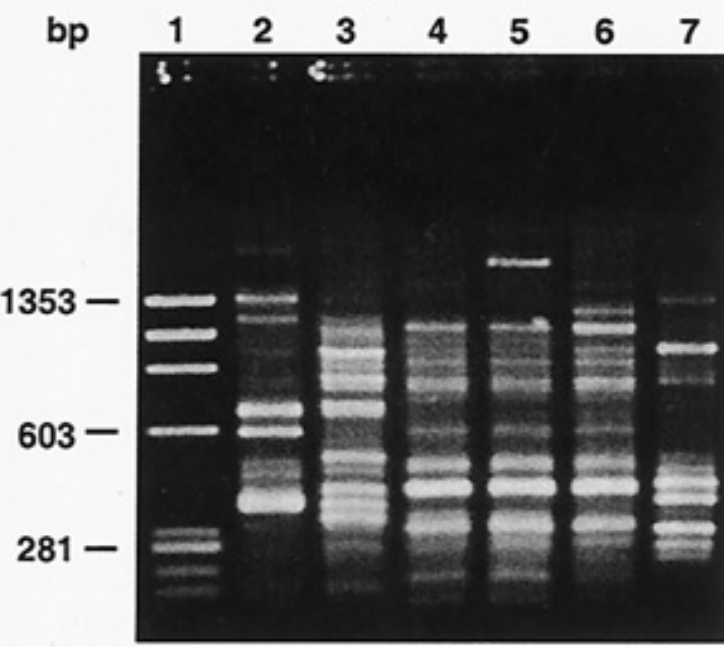

C

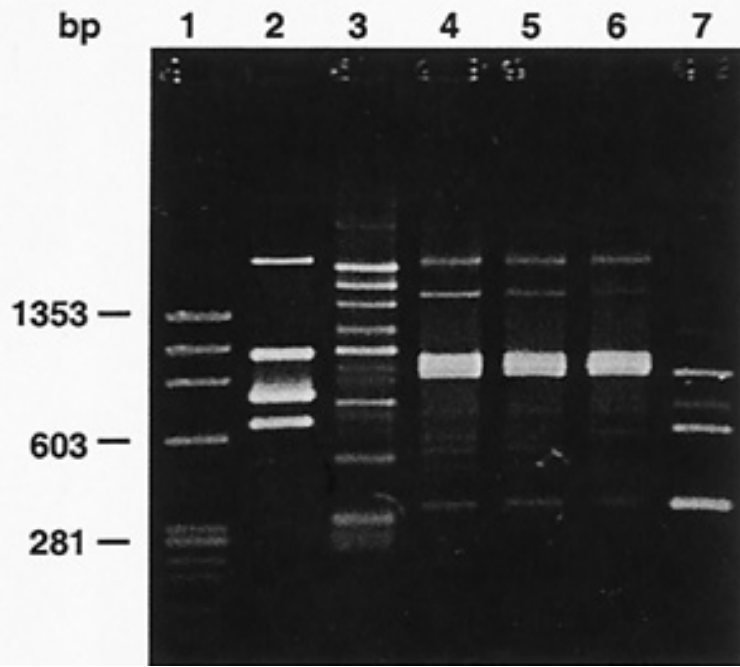

Fig. 1. Polymerase chain reaction of isolates of four Claviceps spp. by $\mathbf{A}$, random amplified microsatellite (RAM) primer set CCA; B, RAM primer set CGA; and C, RAM primer set GT. For A through C, Lane 1 contains size marker $\phi X 174 \mathrm{RF}$ DNA/HaeIII digest; Lane 2 indicates isolate Clp-1 (C. purpurea); Lane 3 indicates isolate Clf-1 (C. fusiformis); Lane 4 indicates isolate Cls-1 (C. africana, India); Lane 5 indicates isolate Cla-2 (C. africana, Australia); Lane 6 indicates isolate Cla-5 (C. africana, TX); and Lane 7 indicates isolate Cjap-2 (C. sorghicola, Japan). (version 2.0; Exeter Biological Software, Setauket, NY). Simple matching coefficients were clustered to generate similarity trees using the SAHN clustering program, selecting the unweighted pair-group method with arithmetic average (UPGMA) algorithm in NTSYS-pc.

\section{RESULTS}

All four sets of RAM primers provided reproducible banding patterns that allowed specie differentiation (Fig. 1). Experiments were repeated at least three times with identical results. Bands ranged from $\approx 200$ to $\approx 2,000 \mathrm{bp}$, and characteristic bands were observed for each species (Fig. 1). Using RAM primer set CGA, only a few band differences were observed in $C$. africana, notably a DNA fragment $\approx 1,200 \mathrm{bp}$ that was present in U.S. isolates but not present in isolates from India or Australia (Fig. 2).

AFLP analysis provided a large number of polymorphic bands for isolate and species comparisons (Fig. 3). The total number of scorable DNA fragments across isolates within the range of 75 to $295 \mathrm{bp}$ was 125 for the AFLP analyses with primer EcoRI + AG in combination with $\mathrm{Mse} \mathrm{I}+\mathrm{C}$, and resulted in a matrix with 3,500 data points. The PCR products of molecular sizes larger than 295 bp were not scored, because resolution was insufficient to discriminate between bands of different molecular sizes. AFLP patterns were highly reproducible, and experiments were repeated at least twice in two laboratories with identical results.

Claviceps spp. showed widely divergent AFLP banding patterns (Fig. 3), and when AFLP data were analyzed by the UPGMA algorithm in NYSYS-pc, Claviceps spp. showed similar values ranging from less than 60 to $\approx 75 \%$ (Fig. 4). C. sorghicola, the recently described species causing sorghum ergot in Japan (24), was more closely related by AFLP analysis to $C$. africana than were C. purpurea or C. fusiformis, which attack other hosts (Fig. 4).

AFLP variation within the four $C$. sorghicola isolates analyzed was less than that observed in C. africana, which ranged from 90 to 100\%. C. africana isolates from Australia (Cla-2 and Cla-3) shared a very prominent DNA fragment $\approx 120 \mathrm{bp}$ in size with isolates from India (Cls-1 to Cls-4 [Fig. 3, arrow]). C. africana isolates from South Africa (Cla-56 and Cla-58) were nearly identical to those from the United States and shared an 111-bp band not present in either Australian (Cla-2 and Cla-3) or Indian (Cls-1 through Cls-4) isolates (Fig. 3, arrow). The four C. africana isolates from India clustered together and showed $\approx 90 \%$ similarity with $C$. africana isolates from Australia, the United States, Puerto

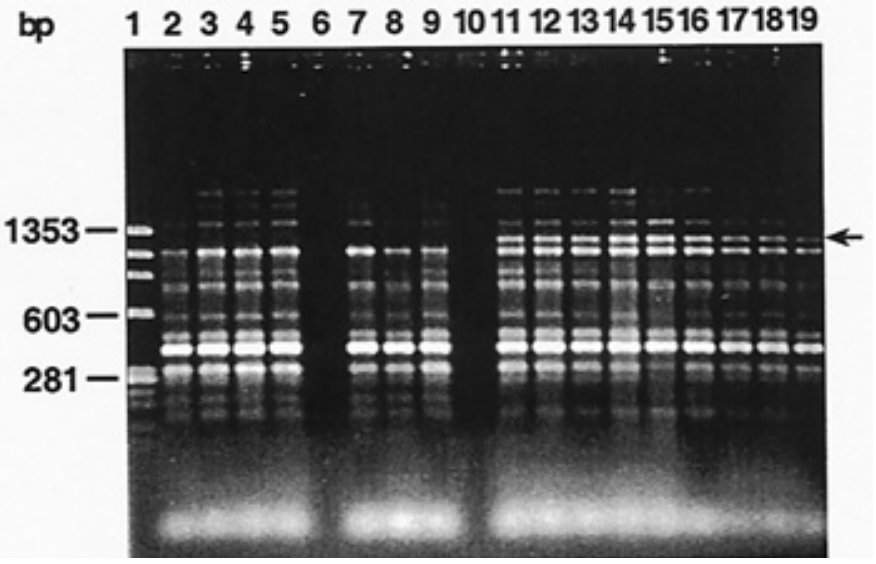

Fig. 2. Polymerase chain reaction of isolates of Claviceps africana by random amplified microsatellite primer set CGA. Lane 1 contains size marker $\phi X 174 \mathrm{RF}$ DNA/HaeIII digest; Lanes 2-5 contain Indian isolates Cls-1, Cls-2, Cls-3, and Cls-4; Lanes 7-9 contain Australian isolates Cla-1, Cla-2, and Cla-3; Lanes 11-19 contain U.S. isolates Cla-4, Cla-5, Cla-7, Cla-8, Cla-9, Cla-10, Cla-12, Cla-14, and Cla-17, respectively. Specific band indicated by arrow in U.S. isolate group and not present in Indian or Australian isolates. 
Rico, and South Africa (Fig. 4). The first isolate obtained from infected sorghum in Nebraska in 1997 (Cla-42) showed 100\% similarity with isolate Cla-34, which originated from the South Coast region (Guayanilla) of Puerto Rico in 1998, and isolates Cla-4, Cla-5, Cla-10, and Cla-49 from three different locations in Texas showed high similarity (95 to $100 \%$ ) with isolates Cla-7, Cla-8, Cla-12, Cla-14, Cla-17, and Cla-25 from Isabela in northwestern Puerto Rico (Fig. 4).

\section{DISCUSSION}

We used RAM and AFLP analysis to perform inter and intraspecific comparisons among isolates of Claviceps spp. causing sorghum ergot in the United States and elsewhere $(1,2,21,24)$. Both RAM and AFLP analyses yielded specific and reproducible banding patterns for isolates and species. Thus, both methods were useful in distinguishing Claviceps spp. from one another and in assessing similarity among isolates. The use of RAM primer sets allowed clear discrimination of species, whereas use of the CGA RAM primer set allowed separation of $C$. africana isolates into two groups based on presence or absence of a specific band. Indian and Australian isolates lacked the DNA fragment of $\approx 1,200 \mathrm{bp}$ that was present in U.S. isolates. The small number of polymorphic bands in $C$. africana limited genetic variation assessment for RAM analyses.

Claviceps isolate and species relationships observed by RAM analysis were supported by AFLP analysis at a higher level of resolution. C. purpurea, C. fusiformis, and C. sorghicola showed less than $75 \%$ similarity with $C$. africana isolates. C. sorghicola, the sorghum pathogen recently described from Japan is distinct from C. africana in terms of morphological (24) and molecular (23) characters. It showed a higher degree of similarity with $C$. africana $(\approx 75 \%)$ based on AFLP analysis than did $C$. purpurea or C. fusiformis, which attack other hosts.

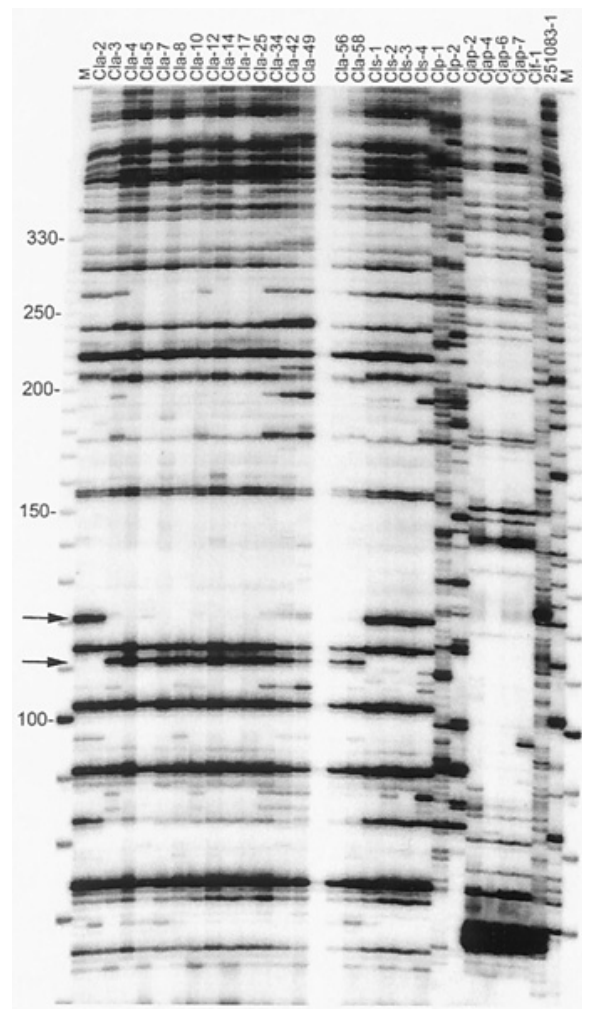

Fig. 3. Gel electrophoresis autoradiograph resulting from amplified fragment length polymorphism analysis of 27 isolates of Claviceps spp. and outgroup species Pleospora papaveracea. Selective amplification was performed with primer combination EcoRI $+\mathrm{AG}$ and $M s e \mathrm{I}+\mathrm{C}$. Molecular sizes (base pairs) are indicated at the left. Arrows indicate polymorphic bands that distinguish Australian and Indian isolates from U.S. and South African isolates.
In C. africana isolates collected from different parts of the world there was 90 to $100 \%$ similarity according to AFLP analysis (Fig. 4), indicating a close taxonomic affinity. Indian $C$. africana isolates (Cls-1 through Cls-4) clustered with $>95 \%$ similarity in the AFLP analysis, and showed $\approx 90 \%$ similarity with other $C$. africana isolates. Previously, the Indian isolates showed identity with other $C$. africana isolates in terms of $\beta$-tubulin and ITS sequences (23). Thus, they represent $C$. africana rather than C. sorghi. The same Indian isolates we analyzed were also identified as C. africana by Bogo and Mantle (4) in describing the occurrence of $C$. africana in India based on morphology and presence of the alkaloid dihydroergosine.

Many isolates showed unique AFLP bands that distinguished them from other isolates with the same geographic origin. Thus, a substantial amount of genetic variation exists in $C$. africana from diverse sources. Even in the U.S. population of isolates, some variation (above 95\% similarity) was observed indicating several clonal genotypes of the pathogen. Variation in U.S. isolates was not observed with RAPDs (21), although all U.S. isolates tested in that study were collected in Texas in the same year.

Indian and Australian isolates showed $\approx 90 \%$ similarity with one another and shared several polymorphic bands (Fig. 3, arrows). This result supports the relationship between isolates from these two locations as observed by RAM analysis and in agreement with the results of Pažoutová et al. (21), who found that Indian and Australian isolates grouped together according to RAPD analysis.

Isolates from different parts of Texas, as well as a single isolate from Nebraska showed high levels of similarity (at or near 100\%) with isolates from Puerto Rico. Puerto Rican samples were ob-

\section{Similarity}

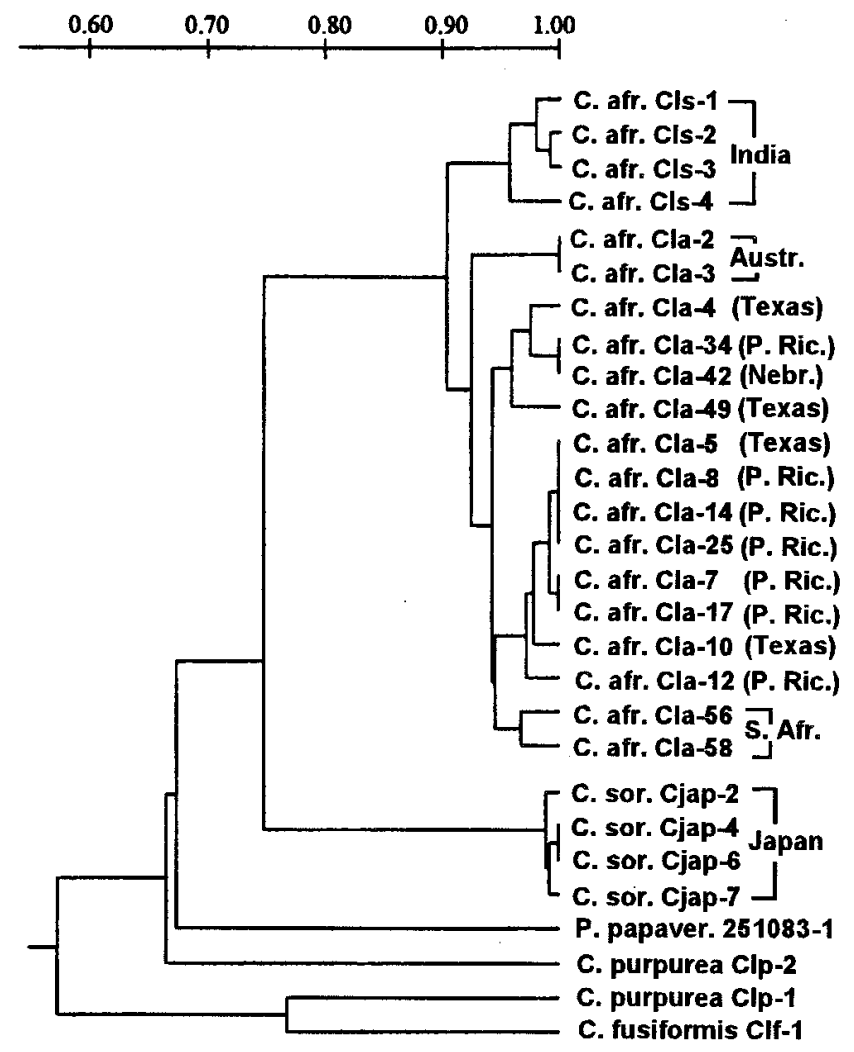

Fig. 4. Dendrogram showing similarities among isolates and species of Claviceps based on amplified fragment length polymorphism analysis using simple matching coefficients. The tree was generated using the SAHN clustering program with the unweighted pair-group method with arithmetic average algorithm in NTSYS-pc. Polymerase chain reaction products between molecular sizes of 75 and 295 bp were scored for the analysis. Species names: C. afr. $=C$. africana; C. sor. $=C$. sorghicola $;$ P. papaver. $=P$. paveracea . 
tained from two areas-Isabela in the Northwest part of the country and Guayanilla on the South Coast. Cla-34 from Guayanilla showed an identical AFLP pattern with Cla-42, which originated from Nebraska during the first ergot outbreak in that state in 1997, whereas Cla- 8 and Cla-14 from Isabela showed an identical pattern with Cla-5 from the original 1997 epidemic in Texas. These samples may represent the genotypes first responsible for infecting U.S. sorghum in 1997. The data suggest that ergot could have spread from Puerto Rico to Texas and other parts of the U.S. in 1997 causing the initial U.S. infestation or that the two 1997 epidemics (Puerto Rico and mainland United States) were initiated by the same clonal genotype originating from a third location. The fact that the U.S. isolates were more similar (95\%) to isolates from South Africa than to Indian or Australian isolates may implicate Africa as the original source of isolates causing the 1997 epidemics in the mainland United States and Puerto Rico $(2,13)$. Supporting this theory is the fact that isolates with identical RAPD patterns were found in South Africa and the Americas (21).

The degree of resolution we obtained with AFLPs for intraspecific analysis parallels results of the population analysis performed on $C$. purpurea by others using RAPDs (14). These results showed that a single RAPD primer was able to distinguish more than $20 \mathrm{C}$. purpurea isolates and that most strains from specific hosts grouped together.

Our studies assessing population diversity and comparing isolates of the sorghum ergot pathogen by RAM and AFLP analyses provide knowledge of the genetic makeup of the $C$. africana population now present in the United States. Furthermore, the methods should prove useful in additional studies of ergot species diversity and in monitoring pathogen isolates in the future. Further analysis of greater numbers of isolates from diverse regions including Africa, India, Australia, South and Central America, and the United States will help determine the potential source of sorghum ergot in the United States and provide more data for assessing levels of genotypic diversity in this rapidly emerging pathogen.

\section{ACKNOWLEDGMENTS}

We thank S. Mevissen and M. Blum for technical assistance, G. Kuldau for technical advice, and R. Frederiksen, G. Odvody, J. Dahlberg, R. Bandyopadhyay, S. Jensen, N. McClaren, and T. Isakeit for providing material for isolation.

\section{LITERATURE CITED}

1. Bandyopadhyay, R., Frederickson, D. E., McLaren, N. W., and Odvody, G. N. 1996. Ergot: A global threat to sorghum. Int. Sorghum Millet Newsl. 37:1-32.

2. Bandyopadhyay, R., Frederickson, D. E., McLaren, N. W., Odvody, G. N., and Ryley, M. J. 1998. Ergot: A new disease threat to sorghum in the Americas and Australia. Plant Dis. 82:356-367.

3. Becker, J., Vos, P., Kuiper, M., Salamini, F., and Heun, M. 1995. Combined mapping of AFLP and RFLP markers in barley. Mol. Gen. Genet. 249:74-81

4. Bogo, A., and Mantle, P. G. 1999. Claviceps africana discovered in India. Plant Dis. 83:79.
5. Borovkov, A. Y., and McClean, P. E. 1993. A tandemly repeated sequence from the Plasmopara halstedii genome. Gene 124:127-130.

6. DeScenzo, R. A., and Harrington, T. C. 1994. Use of (CAT) $)_{5}$ as a DNA fingerprinting probe for fungi. Phytopathology 84:534-540.

7. Farr, D. F., O'Neill, N. R., and van Berkum, P. B. 2000. Morphological and molecular studies on Dendryphion penicillatum and Pleospora papaveracea, pathogens of Papaver somniferum. Mycologia 92:145-153.

8. Folkertsma, R. T., Rouppe van der Voort, N. A. M., de Groot, K. E., van Zandvoort, P. M., Schots, A., Gommers, F. J., Helder, J., and Bakker, J. 1996. Gene pool similarities of potato cyst nematode populations assessed by AFLP analysis. Mol. Plant-Microbe Interact. 9:47-54.

9. Frederickson, D. E., Mantle, P. G., and DeMilliano, W. A. J. 1991. Claviceps africana sp. nov.: The distinctive ergot pathogen of sorghum in Africa. Mycol. Res. 95:1101-1107.

10. Hantula, J., Dusabenyagasani, M., and Hamelin, R. C. 1996. Random amplified microsatellites (RAMS) a novel method for characterizing genetic variation in fungi. Eur. J. For. Path. 26:159-166.

11. Hantula, J., Maarit Niemi, E., Kaitera, J., Jalkanen, R., and Kurkela, T. 1998. Genetic variation of the resin top fungus in Finland as determined by random amplified microsatellites (RAMS). Eur. J. For. Path. 28:361-372.

12. Huyys, G., Coopman, R., Janssen, P., and Kersters, K. 1996. Highresolution genotypic analysis of the genus Aeromonas by AFLP fingerprinting. Inter. J. System. Bacteriol. 46:572-580.

13. Isakeit, T., Odvody, G. N., and Shelby, R. A. 1998. First report of sorghum ergot caused by Claviceps africana in the United States. Plant Dis. 82:592.

14. Jungehulsing, U., and Tudzynski, P. 1997. Analysis of genetic diversity in Claviceps purpurea by RAPD markers. Mycol. Res. 101:1-6.

15. Kulkarni, B. G. P., Seshadri, V. S., and Hegde, R. K. 1976. The perfect stage of Sphacelia sorghi McRae. Mysore J. Agric. Sci. 10:286-289.

16. Lin, J. J., and Kuo, J. 1995. A novel PCR-based assay for plant and bacterial DNA fingerprinting. Focus 17:66-70.

17. Mantle, P. G., and Hassan, H. A. G. 1994. Widening geographical distribution of Claviceps africana, an important ovary pathogen of grain sorghum. Int. Sorghum Millets Newsl. 35:97-98.

18. McRae, W. 1917. Notes on some south Indian fungi. Madras Agric. Yearb. 1917:108-111.

19. Michelmore, R. W., and Hulbert, S. H. 1987. Molecular markers for genetic analysis of phytopathogenic fungi. Annu. Rev. Phytopathol. 25:383-404.

20. O'Neill, N. R., van Berkum, P., Lin, J. J., Kuo, J., Ude, G. N., Kenworthy, W., and Saunders, J. A. 1997. Application of amplified restriction fragment length polymorphism for genetic characterization of Colletotrichum pathogens of alfalfa. Phytopathology 87:745-750.

21. Pažoutová, S., Bandyopadhyay, R., Frederickson, D. E., Mantle, P. G., and Frederiksen, R. A. 2000. Relations among sorghum ergot isolates from the Americas, Africa, India, and Australia. Plant Dis. 84:437-442.

22. Reis, E. M. , Mantle, P. G., and Hassan, H. A.-G. 1996. First report in the Americas of sorghum ergot disease, caused by a pathogen diagnosed as Claviceps africana. Plant Dis. 80:463.

23. Tooley, P. W., Goley, E. D., Carras, M. M., Kuldau, G., Frederick, R. D., and Webber, E. 1999. Sequence analysis of the ITS and $\beta$-tubulin intron 3 regions for differentiation of Claviceps species pathogenic on sorghum. (Abstr.) Phytopathology 89(suppl.):S102

24. Tsukiboshi, T., Shimanuki, T., and Uematsu, T. 1999. Claviceps sorghicola sp. nov., a destructive ergot pathogen of sorghum in Japan. Mycol. Res. 103:1403-1408.

25. van der Lee, T., de Witte, I., Drenth, A., Alfonso, C., and Govers, F 1997. AFLP linkage map of the oomycete Phytophthora infestans. Fungal Genet. Biol. 21:278-291.

26. Vos, P., Hogers, R., Bleeker, M., Reijans, M., van der Lee, T., Jornes, M., Frijters, A., Pot, J., Peleman, J., Kuiper, M., and Zabeau, M. 1995. AFLP: A new technique for DNA fingerprinting. Nucleic Acids Res. 23:4407-4414.

27. Zummo, N., Gourley, L. M., Trevanthan, L. W., and Gonzalez, M. S. 1998. Occurrence of ergot (sugary disease) incited by a Sphacelia sp. on sorghum in Mississippi in 1997. Plant Dis. 82:590. 